(c) American Dairy Science Association, 2004.

\title{
Supplementary Concentrate Type Affects Nitrogen Excretion of Grazing Dairy Cows
}

\author{
F. J. Mulligan, ${ }^{1}$ P. Dillon, ${ }^{3}$ J. J. Callan, ${ }^{2}$ M. Rath, ${ }^{2}$ and F. P. O'Mara ${ }^{2}$ \\ ${ }^{1}$ Department of Animal Husbandry and Production, \\ Faculty of Veterinary Medicine and \\ ${ }^{2}$ Department of Animal Science and Production, \\ Faculty of Agriculture, University College Dublin, \\ Belfield, Dublin 4, Ireland \\ ${ }^{3}$ Dairy Production Department, Teagasc, \\ Moorepark Research Centre, Fermoy, Co. Cork, Ireland
}

\begin{abstract}
These experiments were designed to investigate nutritional means of reducing urine $\mathrm{N}$ excretion by grazing cows. In experiment 1, 36 Holstein-Friesian cows averaging $92 \mathrm{~d}$ in milk were fed either 1 or $6 \mathrm{~kg}$ of a high protein concentrate or $6 \mathrm{~kg}$ of a low protein concentrate. Pasture dry matter (DM) intake was higher for cows fed $1 \mathrm{~kg}$ of high protein concentrate $(15.4 \pm 0.62 \mathrm{~kg} / \mathrm{d})$ than for cows fed $6 \mathrm{~kg}$ of low protein concentrate (13.4 \pm 0.55 ) but not for cows fed $6 \mathrm{~kg}$ of high protein concentrate $(13.9 \pm 0.96)$. The reduction in pasture intake per $\mathrm{kg}$ of concentrate DM ingested amounted to 0.35 and $0.47 \mathrm{~kg}$ of pasture DM for cows fed $6 \mathrm{~kg}$ of high protein and $6 \mathrm{~kg}$ of low protein concentrate, respectively. Milk yield and milk protein yield were higher for cows fed 6 $\mathrm{kg}$ of high protein concentrate than for cows fed $1 \mathrm{~kg}$ of high protein concentrate. Cows fed $6 \mathrm{~kg}$ of high protein concentrate had the highest levels of $\mathrm{N}$ intake, total $\mathrm{N}$ excretion, and urine $\mathrm{N}$ excretion. The proportion of $\mathrm{N}$ excreted in the urine was lowest for cows fed $6 \mathrm{~kg}$ of low protein concentrate. Milk $\mathrm{N}$ excretion as a proportion of ingested $\mathrm{N}$ was higher for cows fed $6 \mathrm{~kg}$ of low protein concentrate than for cows fed $6 \mathrm{~kg}$ of high protein concentrate but not for cows fed $1 \mathrm{~kg}$ of high protein concentrate. In experiment 2, 24 Holstein-Friesian cows averaging $211 \mathrm{~d}$ in milk were supplemented with $4 \mathrm{~kg}$ of rolled barley or $4.32 \mathrm{~kg}$ of $\mathrm{NaOH}$-treated barley. Milk yield and milk protein yield tended to be higher for cows fed rolled barley than for cows fed $\mathrm{NaOH}$-treated barley. There was no difference in $\mathrm{N}$ intake, fecal $\mathrm{N}$ excretion, urinary $\mathrm{N}$ excretion, or milk $\mathrm{N}$ output between diets. Milk urea $\mathrm{N}$ concentration was lower for cows fed rolled barley. Significant positive linear relationships were found between $\mathrm{N}$ intake and fecal $\mathrm{N}$
\end{abstract}

Received January 28, 2004.

Accepted June 12, 2004.

Corresponding author: F. Mulligan; e-mail: finbar.mulligan@ ucd.ie. excretion, urine $\mathrm{N}$ excretion, and milk $\mathrm{N}$ excretion in experiment 1 . In experiment 2 , the relationships between $\mathrm{N}$ intake and fecal $\mathrm{N}$ excretion and urine $\mathrm{N}$ excretion were curvilinear, with urine $\mathrm{N}$ excretion increasing at a decreasing rate, and fecal $\mathrm{N}$ excretion increasing at an increasing rate, as $\mathrm{N}$ intake increased. The $\mathrm{N}$ excreted by dairy cows may be partitioned to fecal $\mathrm{N}$ if supplements based on high concentrations of fermentable organic matter and low concentrations of $\mathrm{N}$ are fed. Refinement of this nutritional strategy may allow reduced $\mathrm{N}$ excretion without reducing animal performance.

(Key words: dairy cow, nitrogen excretion, milk production, grazing)

Abbreviation key: DMD = dry matter digestibility, HP6 = pasture-based diet containing $6 \mathrm{~kg} / \mathrm{d}$ of high protein concentrate, HP1 = pasture-based diet containing $1 \mathrm{~kg} / \mathrm{d}$ of high protein concentrate, $\mathbf{L P 6}=$ pasture-based diet containing $6 \mathrm{~kg} / \mathrm{d}$ of low protein concentrate, $\mathbf{R B}=$ pasture-based diet containing rolled barley, $\mathbf{N a B}=$ pasture-based diet containing sodium hydroxide-treated barley.

\section{INTRODUCTION}

The $\mathrm{N}$ excreted by dairy cows has a detrimental effect on air and water quality (Tamminga, 1992). In particular, urinary $\mathrm{N}$ excretion is a potent source of leached nitrates and gaseous pollutants (Pakrou and Dillon, 1995). Because of this negative environmental impact, dairy farmers in the European Union must adhere to strict environmental controls and cross compliance measures. Several options, including mandatory organic and inorganic $\mathrm{N}$ application rates to land, are available for reducing the negative environmental impact caused by these $\mathrm{N}$ based pollutants. Thus, it is of interest to design feeding programs that would reduce total $\mathrm{N}$ excretion by dairy cows and reduce the proportion of urinary $\mathrm{N}$ in the total $\mathrm{N}$ excreted. 
Several studies have demonstrated that reducing the protein content of the diet reduces total and urinary $\mathrm{N}$ excretion by dairy cows (Colin-Schoelon et al., 2000; Wu and Satter, 2000). With dairy cows fed only pasture, the opportunity to manipulate the protein content of the diet is limited, but where a supplementary concentrate is fed, its protein content could be reduced. However, few studies have examined the effect this has on $\mathrm{N}$ excretion, pasture intake, milk production, and milk composition. Many authors have reported a positive relationship between dietary protein content and DMI (Schor and Gagliostro, 2001; Bargo et al., 2003), which will affect $\mathrm{N}$ excretion and milk production. Thus, when investigating the effect of reducing the protein content of the supplementary concentrate on the type and amount of $\mathrm{N}$ excreted, it is important to also investigate the impact on pasture intake and milk production.

It has also been suggested that shifting the site of digestion from the rumen to the large intestine has the potential to reduce urinary $\mathrm{N}$ excretion (Castillo et al., 2001b). This has been demonstrated by comparing corn grain and barley or wheat as starch sources for lactating cows fed grass silage-based diets (Kebreab et al., 2000; Castillo et al., 2001b). However, there is a scarcity of data in the literature concerning the effect that site of supplemental carbohydrate digestion has on $\mathrm{N}$ excretion by dairy cows grazing perennial ryegrass-based pasture, which likely contains higher levels of ruminally fermentable OM than grass silage. It has been demonstrated that $\mathrm{NaOH}$ treatment reduces the ruminal degradability of barley (McNiven et al., 1995) and wheat (O'Mara et al., 1997). This cereal processing method could be an alternative to corn grain in areas where it is too cold for it to grow and where it is more expensive than other cereals. However, the efficacy of $\mathrm{NaOH}$-treated grain at reducing urinary $\mathrm{N}$ excretion needs to be determined.

Therefore, this work investigates 2 methods of reducing total $\mathrm{N}$ excretion and $\mathrm{N}$ excretion in the urine of dairy cows: 1) reducing concentrate protein content, which was the objective of experiment 1 ; and 2) shifting the site of cereal digestion to the large intestine, which was the objective of experiment 2 .

\section{MATERIALS AND METHODS}

\section{Animals and Management}

In experiment 1, 30 multiparous and 6 primiparous Holstein-Friesian dairy cows were blocked on milk yield and previous nutritional history and randomly assigned to 1 of 3 pasture-based feeding systems for a period of 7 wk. This 7 -wk period included a 3-wk acclimation period and a 4-wk experimental period. Treatments consisted of 1) a pasture-based diet containing $1 \mathrm{~kg} / \mathrm{d}$ of
Table 1. Ingredient composition of compound feeds used in experiments 1 and 2 .

\begin{tabular}{|c|c|c|}
\hline \multirow[b]{2}{*}{ Ingredient (\%) } & \multicolumn{2}{|c|}{ Experiment 1} \\
\hline & $\begin{array}{l}\text { Low protein } \\
\text { compound }\end{array}$ & $\begin{array}{l}\text { High protein } \\
\text { compound }\end{array}$ \\
\hline Citrus pulp & 45.0 & 27.4 \\
\hline Sugar beet pulp & 45.0 & 27.4 \\
\hline Soybean meal (Hipro) & 0.0 & 35.5 \\
\hline Molasses (cane) & 5.0 & 5.0 \\
\hline Palm oil & 1.4 & 1.5 \\
\hline Monodicalcium phosphate & 1.9 & 0.9 \\
\hline Salt & 0.5 & 0.6 \\
\hline Calcined magnesite & 0.95 & 1.43 \\
\hline \multirow[t]{3}{*}{ Trace elements and vitamins ${ }^{1}$} & 0.26 & 1.31 \\
\hline & \multicolumn{2}{|c|}{ Experiment 2} \\
\hline & \multicolumn{2}{|c|}{$\begin{array}{l}\text { Dairy } \\
\text { compound }\end{array}$} \\
\hline Wheat & \multicolumn{2}{|l|}{30.5} \\
\hline Corn distillers grains & \multicolumn{2}{|l|}{15.1} \\
\hline Cotton seed meal (extracted) & \multicolumn{2}{|l|}{15.0} \\
\hline Palm kernel meal (expeller) & \multicolumn{2}{|l|}{11.5} \\
\hline Citrus pulp & \multirow{2}{*}{\multicolumn{2}{|c|}{$\begin{array}{l}7.5 \\
6.5\end{array}$}} \\
\hline Milk solids extract & & \\
\hline Soya hulls & \multicolumn{2}{|l|}{5.7} \\
\hline Copra meal (extracted) & \multicolumn{2}{|l|}{5.0} \\
\hline Limestone flour & \multicolumn{2}{|l|}{0.9} \\
\hline Palm oil & \multicolumn{2}{|l|}{0.5} \\
\hline Calcined magnesite & \multicolumn{2}{|l|}{1.3} \\
\hline Trace elements and vitamins ${ }^{2}$ & \multicolumn{2}{|l|}{0.5} \\
\hline
\end{tabular}

${ }^{1}$ The low-protein compound contained $65 \mathrm{mg} / \mathrm{kg} \mathrm{Cu}, 0.63 \mathrm{mg} / \mathrm{kg} \mathrm{Se}$, $100 \mathrm{mg} / \mathrm{kg} \mathrm{Zn}, 25 \mathrm{mg} / \mathrm{kg} \mathrm{Mn}, 0.63 \mathrm{mg} / \mathrm{kg} \mathrm{Co}, 7.5 \mathrm{mg} / \mathrm{kg} \mathrm{I}, 13,500 \mathrm{IU} /$ $\mathrm{kg}$ vitamin $\mathrm{A}, 2750 \mathrm{IU} / \mathrm{kg}$ vitamin $\mathrm{D}_{3}$, and $5 \mathrm{IU} / \mathrm{kg}$ vitamin $\mathrm{E}$. The high-protein compound contained $82 \mathrm{mg} / \mathrm{kg} \mathrm{Cu}, 0.75 \mathrm{mg} / \mathrm{kg}$ Se, 120 $\mathrm{mg} / \mathrm{kg} \mathrm{Zn}, 30 \mathrm{mg} / \mathrm{kg} \mathrm{Mn}, 0.75 \mathrm{mg} / \mathrm{kg}$ Co, $9 \mathrm{mg} / \mathrm{kg} \mathrm{I}, 16,200 \mathrm{IU} / \mathrm{kg}$ vitamin $\mathrm{A}, 3,300 \mathrm{IU} / \mathrm{kg}$ vitamin $\mathrm{D}_{3}$, and $6 \mathrm{IU} / \mathrm{kg}$ vitamin $\mathrm{E}$.

${ }^{2}$ The dairy compound in experiment 2 contained $52 \mathrm{mg} / \mathrm{kg} \mathrm{Cu}, 0.65$ $\mathrm{mg} / \mathrm{kg} \mathrm{Se}, 10 \mathrm{mg} / \mathrm{kg} \mathrm{I}, 6000 \mathrm{IU} / \mathrm{kg}$ vitamin A, $2000 \mathrm{IU} / \mathrm{kg}$ vitamin D3, and $10 \mathrm{IU} / \mathrm{kg}$ vitamin $\mathrm{E}$.

high protein concentrate (HP1) $(24 \%$ CP), 2) a pasturebased diet containing $6 \mathrm{~kg} / \mathrm{d}$ of high protein concentrate (HP6) (24\% CP), and 3) a pasture-based diet containing $6 \mathrm{~kg} / \mathrm{d}$ of low protein concentrate (LP6) (9\% CP). The high-protein concentrate contained unmolassed sugar beet pulp, citrus pulp, and soybean meal as the main ingredients; the low-protein concentrate contained unmolassed sugar beet pulp and citrus pulp as the main ingredients (Table 1) (Gain Feeds, Glanbia Foods Society Ltd., Kilkenny, Ireland). All cows were fed the concentrate portion of their diet twice daily at each milking. All cows were grazed together, and a pasture allowance of $20 \mathrm{~kg} / \mathrm{d}$ of DM per cow (measured at a cutting height of $4 \mathrm{~cm}$ ) was maintained across the 3 treatments. Pasture allowance allocation was facilitated by measurement of pasture cover with a falling plate meter assuming that $200 \mathrm{~kg}$ of DM/ha per $\mathrm{cm}$ were available above a pasture height of $4 \mathrm{~cm}$. Appropriate paddock areas for the entire group were allocated each day based on 
pasture cover. The average pregrazing pasture cover was $2277 \pm 593 \mathrm{~kg}$ of DM/ha, average pregrazing compressed pasture height was $15.4 \pm 2.97 \mathrm{~cm}$, and average postgrazing pasture cover and compressed pasture height were $557 \pm 241 \mathrm{~kg}$ of DM/ha and $6.8 \pm 1.20 \mathrm{~cm}$, respectively. The pasture used in this experiment was estimated to contain $40 \%$ perennial ryegrass (Lolium perenne, $L$ ), $40 \%$ rough-stalked meadow grass (Poa trivialis), $40 \%$ annual meadow grass (Poa annua), and 10\% white clover (Trifolium repens $L$.). These pastures received $57 \mathrm{~kg}$ of inorganic N/ha in February, $57 \mathrm{~kg}$ of inorganic N/ha in March, and $68 \mathrm{~kg}$ of inorganic N/ha in early April.

The cows used in experiment 1 averaged 92 DIM at the start of the experiment, had an average preexperimental milk yield of $32.3 \pm 3.9 \mathrm{~kg} / \mathrm{d}$ and an average preexperimental milk protein yield of $1084 \pm 135 \mathrm{~g} / \mathrm{d}$. The average 305-d milk yield recorded for this group in this lactation was $6939 \pm 943 \mathrm{~kg}$. Holstein genes made up $61.4 \pm 12.1 \%$ of the genes in these cows with the remainder being Friesian. Experiment 1 was carried out during April and May.

In experiment 2, 18 multiparous and 6 primiparous cows averaging $211 \mathrm{DIM}$ (at the beginning of the experiment) with average preexperimental milk and milk protein yields of $19.6 \pm 2.22 \mathrm{~kg} / \mathrm{d}$ and $694 \pm 82.1 \mathrm{~g} / \mathrm{d}$, respectively, were blocked based on preexperimental milk yield and stage of lactation and randomly assigned to 1 of 2 treatments for a 7-wk experimental period. This 7 -wk period included a 3 -wk acclimation period and a 4-wk experimental period. Treatments were a pasturebased diet containing rolled barley $(\mathbf{R B})$ and a pasturebased diet containing sodium hydroxide-treated barley (NaB). The RB contained $4 \mathrm{~kg}$ of rolled barley, $400 \mathrm{~g}$ of molasses, and $100 \mathrm{~g}$ of a mineral-vitamin premix in addition to pasture, and $\mathrm{NaB}$ contained $4.32 \mathrm{~kg}$ of $\mathrm{NaOH}$-treated barley, $400 \mathrm{~g}$ of molasses, and $100 \mathrm{~g}$ of a mineral-vitamin premix in addition to pasture. The mineral and vitamin premix contained $20.7 \% \mathrm{Ca}, 10.0 \%$ $\mathrm{Na}, 8.0 \% \mathrm{P}, 5.0 \% \mathrm{Mg}, 1000 \mathrm{mg} / \mathrm{kg}$ I, $50 \mathrm{mg} / \mathrm{kg} \mathrm{Se}, 5000$ $\mathrm{mg} / \mathrm{kg} \mathrm{Cu}, 3000 \mathrm{mg} / \mathrm{kg} \mathrm{Mn}, 250 \mathrm{mg} / \mathrm{kg} \mathrm{Co}, 6000 \mathrm{mg} / \mathrm{kg}$ $\mathrm{Zn}, 300,000 \mathrm{IU} / \mathrm{kg}$ vitamin $\mathrm{A}, 60,000 \mathrm{IU} / \mathrm{kg}$ vitamin $\mathrm{D}_{3}$, and $600 \mathrm{mg} / \mathrm{kg}$ of vitamin $\mathrm{E}$. In addition, all cows were fed $1 \mathrm{~kg} / \mathrm{d}$ of dairy compound (Table 1) (Gain Feeds, Glanbia Foods Society Ltd.). The average 305-d milk yield of the cows used in this lactation was $6983 \pm 949$ $\mathrm{kg}$, and the average proportion of Holstein genes of these cows was $61.7 \pm 15.1 \%$ with the remainder of the genes being Friesian. Daily pasture allowance (determined as for experiment 1) was $20 \mathrm{~kg}$ of DM/ha with average pregrazing pasture cover (measured at a cutting height of $4 \mathrm{~cm}$ ) of $1352 \pm 211 \mathrm{~kg}$ of DM/ha and average pregrazing compressed pasture height of 11.0 $\pm 1.06 \mathrm{~cm}$. Experiment 2 was carried out during the months of September and October. The barley used in this experiment was of the variety Ashling and was grown at Lyons Research Farm. For $\mathrm{NaOH}$ treatment, $50 \mathrm{~kg}$ of NaOH/tonne of barley was dry-mixed in a mixer wagon for $5 \mathrm{~min}$. Subsequently, $60 \mathrm{~L}$ of water/tonne of barley was added to the mixer wagon, and mixing continued for $20 \mathrm{~min}$. This was followed by the addition of a further $200 \mathrm{~L}$ of water/tonne of barley and mixing for $5 \mathrm{~min}$. The $\mathrm{NaOH}$-treated barley was then discharged from the mixer wagon and left in a heap for 5 $\mathrm{h}$ prior to spreading to a depth of $30 \mathrm{~cm}$ on a concrete floor. Finally, after $5 \mathrm{~d}$, the barley was reloaded into the mixer wagon, remixed, and discharged to a produce $\mathrm{NaOH}$-treated barley that was free of large aggregations. The rolled or $\mathrm{NaOH}$-treated barley mix was fed in equal halves immediately after each milking using individual self-locking head stalls.

\section{Milk Sampling}

In both experiments, cows were milked twice daily at 0530 and $1530 \mathrm{~h}$. Milk yield was determined by automatic recording of the milk yield of each cow for each day of both experiments. Milk was sampled twice weekly during each of the 4 experimental weeks in each experiment. Milk samples were taken at consecutive evening and morning milkings and pooled in proportion to yield immediately following the morning milking. Each sample was then analyzed for milk protein $(\mathrm{N} \times$ 6.38) and milk fat (Gerber method) content. Milk N concentration was determined using a Leco FP-528 N analyzer (LECO Corporation, St. Joseph, MI). In experiment 2, milk urea content was determined using the Randox colorimetric method (Cat. No. UR 228; Randox Laboratories, Crumlin, Co. Antrim, UK). For this analysis, samples were prepared by mixing $1 \mathrm{~mL}$ of milk with $4 \mathrm{~mL}$ of trichloroacetic acid $(0.3 \mathrm{~mol} / \mathrm{L})$. After approximately $5 \mathrm{~min}$, samples were centrifuged for separation of the precipitate, and the supernatant clear solution $(10 \mu \mathrm{L})$ was used for the assay.

\section{Intake and Digestibility Determination}

Daily pasture DMI and diet DM digestibility (DMD) were estimated for a period of $6 \mathrm{~d}$ in each experiment. Pasture DMI determination used the n-alkane technique of Mayes et al. (1986) as modified by Dillon and Stakelum (1989). Immediately after each milking, each cow was dosed orally with a paper bung (a cube of highly absorbent compacted paper) that was impregnated with the n-alkane C32 (n-dotriacontane) for a period of 12 d. Each paper bung was estimated to contain $500 \mathrm{mg}$ of C32. During the last $6 \mathrm{~d}$ of this oral dosing period, fecal samples were taken per rectum for each cow twice 
daily. The fecal samples for each cow were immediately frozen at $-20^{\circ} \mathrm{C}$ and later pooled for analysis. The fecal samples used for this determination were dried for a period of $96 \mathrm{~h}$ at $40^{\circ} \mathrm{C}$ in a fan-assisted oven. The ratio of pasture C33 (tritriacontane) to dosed C32 was used to estimate voluntary DMI using the equation

$$
\frac{\mathrm{Fi} / \mathrm{Fj} \times(\mathrm{Dj}+\mathrm{Ic} \times \mathrm{Cj})-\mathrm{Ic} \times \mathrm{Ci}}{\mathrm{Hi}-(\mathrm{Fi} / \mathrm{Fj} \times \mathrm{Hj})}
$$

where $\mathrm{Fi}$ and $\mathrm{Fj}$ are the concentrations of naturally occurring odd-chain (mainly feed derived C33) and even-chain (mainly dosed C32) n-alkanes in feces (mg/ $\mathrm{kg} \mathrm{DM}$ ), respectively; $\mathrm{Hi}$ and $\mathrm{Hj}$ are concentrations of natural odd-chain and even-chain n-alkanes in pasture $(\mathrm{mg} / \mathrm{kg} \mathrm{DM})$, respectively; $\mathrm{Ci}$ and $\mathrm{Cj}$ are concentrations of natural odd-chain and even-chain n-alkanes in the concentrates fed $(\mathrm{mg} / \mathrm{kg} \mathrm{DM})$, respectively; $\mathrm{Dj}$ is the daily dose of even-chain $\mathrm{n}$-alkanes $(\mathrm{mg} / \mathrm{d})$; and Ic is the daily concentrate intake $(\mathrm{kg} / \mathrm{d})$. Diet DMD was determined based on the concentration of the natural odd-chain n-alkane C35 (pentatriacontane) in the feces and in the total diet following pasture and concentrate analysis using the equation

\section{$1-$}

(dietary C35 concentration/fecal C35 concentration).

For this exercise, the recovery of C35 in the feces of dairy cows was assumed to be 0.915 (Dillon, 1993). Samples of pasture consumed were taken twice daily by following grazing dairy cows and taking pasture clippings at the same sites and to the same pasture height as grazing was observed. These daily samples were pooled and later freeze-dried prior to n-alkanes analysis.

\section{N Excretion and N Metabolism}

Quantities of $\mathrm{N}$ excreted in the feces were calculated from the indigestibility of the diet fed and fecal $\mathrm{N}$ content. Urine $\mathrm{N}$ excretion was determined by subtracting the $\mathrm{N}$ excreted in feces and milk from total $\mathrm{N}$ intake (Van Vuuren et al., 1993). In experiment 2, urine samples were taken twice daily for 5 consecutive $d$ after evening milking. These samples were immediately frozen and later pooled for analysis. Vulval stimulation was used to induce cows to urinate, and the urine that was voided was sampled.

\section{Chemical Analysis}

Pasture and concentrate samples were collected daily during the experimental periods and pooled on a period basis for analysis. For DM determination and for routine chemical analysis, both pasture and fecal samples were dried at $55^{\circ} \mathrm{C}$ for $4 \mathrm{~d}$ while concentrate feed samples were dried at $104^{\circ} \mathrm{C}$ for $16 \mathrm{~h}$. Feed and fecal samples were ground in a hammer mill fitted with a 1-mm screen. The $\mathrm{N}$ content of feed and fecal samples was determined using a Leco FP-528 N Analyzer (LECO Corporation). Crude protein was determined as $\mathrm{N}$ content $\times 6.25$ for feed and fecal samples. The methods used for analysis of NDF, ADF, acid detergent lignin, ash, and DM are described by Mulligan et al. (2002). Urinary urea concentration was determined using the Randox colorimetric method (Cat No. UR 228) as described previously for milk, after urine was diluted at 1:20 with distilled water. Urinary creatinine concentration was also determined using a Randox colorimetric method (Cat No. CR 510); urinary allantoin concentration was determined using the method of Borcher (1977). The concentrations of C32, C33, and C35 in the feces, pasture and the concentrates fed were determined as described by Dillon (1993). The fecal samples used for n-alkanes analysis were dried at $40^{\circ} \mathrm{C}$ for a period of $96 \mathrm{~h}$; the pasture samples used in this analysis were freeze-dried.

\section{Statistical Analysis}

In experiment 1 , cows were blocked on milk yield, DIM, and previous nutritional history and randomly allocated to 1 of 3 treatments. The data for experiment 1 were analyzed as a randomized block design using ANOVA and the PROC GLM statement of SAS with preexperimental production values used as covariables in the model for milk yield, milk composition, and milk component yield. The model used for pasture DMI, total DMI, diet DMD, $\mathrm{N}$ intake, fecal $\mathrm{N}$ excretion, milk $\mathrm{N}$ output, urine $\mathrm{N}$ excretion, total $\mathrm{N}$ excretion, $\mathrm{N}$ excretion as a percentage of ingested $\mathrm{N}$, and urine $\mathrm{N}$ excretion as a percentage of $\mathrm{N}$ excreted in feces and urine included treatment, block, parity, and previous nutritional history as sources of variation. Means were compared using Student's $t$-test with significance indicated at $P<$ 0.05 . The relationship between $\mathrm{N}$ intake and fecal $\mathrm{N}$ excretion, urinary $\mathrm{N}$ excretion, milk $\mathrm{N}$ excretion, $\mathrm{N}$ excretion as a percentage of ingested $\mathrm{N}$, and urine $\mathrm{N}$ excretion as a percentage of total $\mathrm{N}$ excretion was tested for linear and curvilinear effects using the PROC GLM statement of SAS.

In experiment 2, cows were blocked on preexperimental milk yield and DIM and randomly assigned to 1 of 2 treatments. The data for pasture DMI, concentrate $\mathrm{DMI}$, total DMI, diet DMD, fecal $\mathrm{N}$ excretion, urine $\mathrm{N}$ excretion, $\mathrm{N}$ excretion as a percentage of $\mathrm{N}$ intake, urine $\mathrm{N}$ excretion as a percentage of total $\mathrm{N}$ excretion, milk 
urea $\mathrm{N}$, urinary allantoin $\mathrm{N}$ :creatinine $\mathrm{N}$, and urinary urea $\mathrm{N}$ :creatinine $\mathrm{N}$ were analyzed as a randomized block design using ANOVA and the PROC GLM statement of SAS. The sources of variation included in the model for this analysis included treatment, block, parity, and pregnancy status. For milk yield, milk composition, and milk component yield, preexperimental production values were used as covariables in the model. Means were compared using Student's $t$-test with significance indicated at $P<0.05$. The relationship between $\mathrm{N}$ intake and fecal $\mathrm{N}$ excretion, milk $\mathrm{N}$ excretion, urinary $\mathrm{N}$ excretion, and urinary $\mathrm{N}$ excretion as a percentage of total $\mathrm{N}$ excretion were tested for linear and curvilinear effects using the PROC GLM statement of SAS. In addition, the relationship between milk urea $\mathrm{N}$ concentration and the excretion of $\mathrm{N}$ in the urine was investigated in this manner.

\section{RESULTS AND DISCUSSION}

The chemical composition of the pasture and supplements used in both experiments is presented in Table 2 . The milk production and $\mathrm{N}$ excretion data for experiment 1 are presented in Tables 3 and 4, respectively, and those for experiment 2 in Tables 5 and 6.

The methodology used in these experiments has assumed negligible levels of $\mathrm{N}$ retention. Similarly, several researchers (Van Vuuren et al., 1993; Wu and Satter, 2000) have published estimates of urine $\mathrm{N}$ excretion based on the difference between total ingested $\mathrm{N}$ and $\mathrm{N}$ excretion in feces and milk as used in these experiments. In addition, after reviewing data from 91 different diets fed to 580 dairy cows, Castillo et al. (2000) concluded that $98 \%$ of ingested $\mathrm{N}$ is recovered in the feces, urine, and milk, although higher proportions of $\mathrm{N}$ may be retained when cows are increasing in BW. The pregnant cows used in experiment 2 were unlikely to have retained large quantities of $\mathrm{N}$ in the fetus. The average stage of gestation for these cows was unlikely to have been $>190 \mathrm{~d}$ during this experiment, given that they were, on average, 211 DIM at the beginning of the experiment. This fact is significant as the protein requirements for the fetus prior to this stage of pregnancy are low and are not considered before $190 \mathrm{~d}$ of gestation (NRC, 2001). The n-alkane technique of estimating pasture DMI and diet DMD has been found to estimate both parameters accurately by Dillon and Stakelum (1989) and Dillon (1993). The use of spot urine samples and analysis of allantoin:creatinine $\mathrm{N}$ for estimating ruminal microbial protein yield in grazing cows has equaled total urine collection by Bargo et al. (2002).

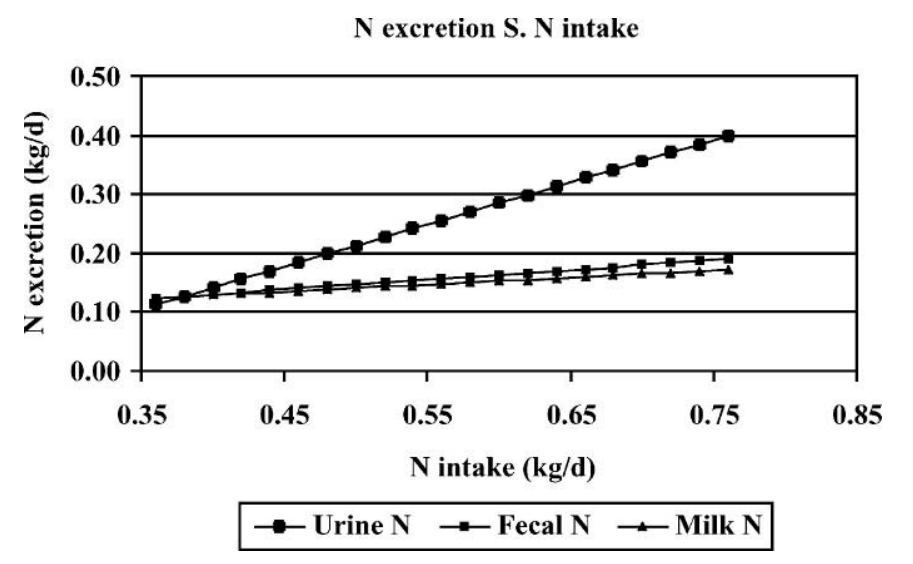

Figure 1. Pattern of urinary, fecal, and milk $\mathrm{N}$ excretion plotted over the $\mathrm{N}$ intake range observed for cows in Experiment 1.

\section{N Excretion}

Nitrogen intake in experiment 1 ranged from 360 to $757 \mathrm{~g} / \mathrm{d}$. No difference $(P=0.46)$ was observed in N intake between cows fed HP1 and cows fed LP6 (average $\mathrm{N}$ intake $=491 \mathrm{~g} / \mathrm{d}$ ). Cows fed HP6 had a much higher $(P<0.01) \mathrm{N}$ intake than cows fed either HP1 or LP6 (Table 4). However, $\mathrm{N}$ excretion in the feces and in milk was not increased for the cows fed HP6 $(P>0.20)$. Thus, assuming that $\mathrm{N}$ retention was minimal, most of the extra $\mathrm{N}$ ingested by cows fed this diet was partitioned to the urine. Peyraud and Astigarraga (1998) have made similar observations for dairy cows using diets based on mixed forages and grass. In addition, Castillo et al. (2001a) demonstrated a significant increase in urine $\mathrm{N}$ excretion without a significant increase in fecal $\mathrm{N}$ or milk $\mathrm{N}$ excretion after $\mathrm{N}$ intake increased from 422 to $516 \mathrm{~g} / \mathrm{d}$ for cows fed grass silage-based diets. The percentage of ingested $\mathrm{N}$ that was excreted in the feces and urine ranged from 66.9 to $80.3 \%$ in experiment 1 . Cows fed LP6 had a lower $(P<0.05)$ percentage of ingested $\mathrm{N}$ that was excreted in the feces and urine (70.5\%) compared with cows fed HP6 but a similar ( $P$ $>0.05$ ) percentage compared with cows fed HP1 (Table 4). The proportion of $\mathrm{N}$ excreted in feces and urine that was excreted in the urine was lower $(P<0.05)$ for cows fed LP6 (53.7\%) than for cows fed HP6 (66.3\%) and HP1 $(62.3 \%)$.

Significant positive linear relationships were observed between $\mathrm{N}$ intake and urine $\mathrm{N}$ excretion, fecal $\mathrm{N}$ excretion, milk $\mathrm{N}$ excretion (Figure 1), $\mathrm{N}$ excretion/ $\mathrm{N}$ intake (\%), and urinary $\mathrm{N}$ excretion/total $\mathrm{N}$ excretion (\%) (Eq. [1] to [5]).

Urine $\mathrm{N}(\mathrm{kg} / \mathrm{d})=-0.145( \pm 0.0428)+0.716( \pm 0.0760)$
$\times$ 
Fecal N $(\mathrm{kg} / \mathrm{d})=0.064( \pm 0.0329)+0.165( \pm 0.0584)$

$\times \mathrm{N}$ intake $(\mathrm{kg} / \mathrm{d}) ; R^{2}=0.21 ; P<0.01$

Milk N $(\mathrm{kg} / \mathrm{d})=0.081( \pm 0.0183)+0.119( \pm 0.0325)$

$\times \mathrm{N}$ intake $(\mathrm{kg} / \mathrm{d}) ; R^{2}=0.30 ; P<0.0001$

$\mathrm{N}$ excretion $/ \mathrm{N}$ intake $(\%)=0.591( \pm 0.0293)$

$+0.253( \pm 0.0511) \times \mathrm{N}$ intake $(\mathrm{kg} / \mathrm{d})$;

$$
R^{2}=0.43 ; P<0.0001
$$

Urinary $\mathrm{N}$ excretion/total $\mathrm{N}$ excretion $(\%)=0.331$

$( \pm 0.948)+0.494( \pm 0.168) \times \mathrm{N}$ intake $(\mathrm{kg} / \mathrm{d}) ;$

$$
R^{2}=0.22 ; P<0.01
$$

The increasing proportion of $\mathrm{N}$ excretion in urine and feces accounted for by urine $\mathrm{N}$ excretion as $\mathrm{N}$ intake increases is important given that much higher levels of urinary $\mathrm{N}$ are volatilized as ammonia in comparison to fecal N (Lockyer and Whitehead, 1990) and its greater capacity for soil penetration (Pakrou and Dillon, 1995). Several researchers have reported that increasing $\mathrm{N}$ intake increases the percentage of excreted $\mathrm{N}$ excreted in the urine (Van Vuuren et al., 1993; Castillo et al., 2001a). For cows fed HP1 and LP6, N intake was very similar. However, the proportion of $\mathrm{N}$ excreted in the feces versus that excreted in urine was much lower for cows fed LP6 (Table 4). The lower urinary N excretion by cows fed LP6 might have been due to the large amount of fermentable OM supplied by the unmolassed sugar beet pulp and citrus pulp-containing concentrate supplement. This supplement should have had the effect of increasing rumen degraded $\mathrm{N}$ incorporation into microbial protein, a considerable proportion of which is excreted in the feces. Other researchers have also identified the need to reduce excess RDP in the diet as a means of reducing $\mathrm{N}$ excretion in the urine (Hvelplund and Madsen, 1996). These observations agree with those of Van Vuuren et al. (1993) who observed that supplementing perennial ryegrass diets with high fiber concentrates reduced rumen $\mathrm{NH}_{3}$ and urinary $\mathrm{N}$ excretion and increased fecal N excretion. Similarly, Bargo et al. (2002) observed a reduction in urinary $\mathrm{N}$ excretion as a percentage of ingested $\mathrm{N}$ after offering concentrate supplements to cows fed pasture only.

In experiment 1 , the percentage of ingested $\mathrm{N}$ excreted in the feces and urine was $71.1 \%$ for HP1, 74.7\% for HP6, and 70.5\% for LP6 (Table 4). These values are much lower than those observed in experiment 2 , which were $82.6 \%$ for $\mathrm{RB}$ and $84.3 \%$ for $\mathrm{NaB}$ (Table 6 ). However, both estimates of the percentage of ingested $\mathrm{N}$ excreted in the feces are well within reported ranges (Tamminga, 1992; Van Vuuren et al., 1993). It is likely that the much lower $\mathrm{CP}$ requirements of the cows in
Table 2. Chemical composition of the pasture and concentrates fed. Values in $\mathrm{g} / \mathrm{kg} \mathrm{DM}$, except DM, g/kg.

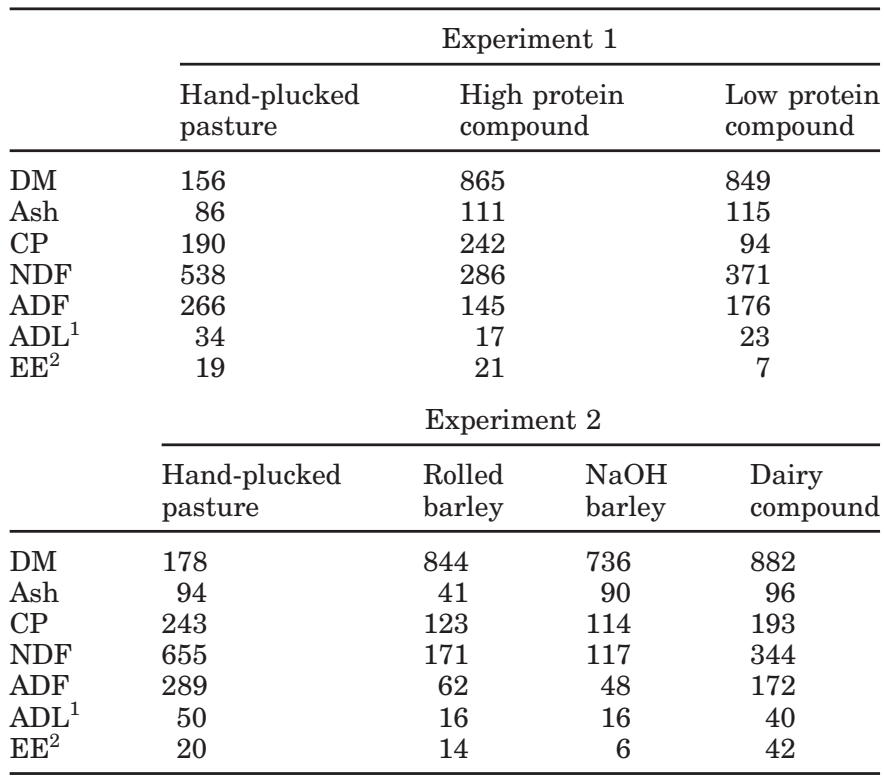

${ }^{1} \mathrm{ADL}=$ Acid detergent lignin.

${ }^{2} \mathrm{EE}=$ Ether extract.

experiment 2 , which were in later lactation, contributed to the increased percentage of ingested $\mathrm{N}$ excreted in this case. In common with other experiments (ColinSchoelon et al., 2000), the efficiency of ingested N use in milk was higher for the low N intake diets, HP1 and LP6, in experiment 1. For HP1, 28.9\% of ingested N was recovered in milk; for LP6, 29.5\% of ingested N was recovered in milk. For HP6, only $25.3 \%$ of ingested $\mathrm{N}$ was recovered in milk. These values are similar to those reported by Sloan et al. (1988) for diets based on grass silage ( 24.8 to $30.8 \%$ ), but are higher than those (15.7 to 20.6\%) reported by Bargo et al. (2002) for cows grazing pastures containing mainly smooth bromegrass and orchardgrass.

The $\mathrm{N}$ intake values observed for the cows used in experiment 2 ranged from 451 to $799 \mathrm{~g} / \mathrm{d}$. There was no significant difference observed in $\mathrm{N}$ intake between cows fed $\mathrm{RB}$ and those fed $\mathrm{NaB}$ (average $\mathrm{N}$ intake = $626 \mathrm{~g} / \mathrm{d}$ ) (Table 6). Similarly, there was no difference between treatments in milk $\mathrm{N}$ excretion, fecal $\mathrm{N}$ excretion, urine $\mathrm{N}$ excretion, $\mathrm{N}$ excretion as a percentage of $\mathrm{N}$ intake, or the proportion of $\mathrm{N}$ excreted in feces and urine that was excreted in the urine $(P>0.05)$. It had been reported that sources of cereal starch, which are less degradable in the rumen, reduce urinary $\mathrm{N}$ excretion in comparison with supplements containing high levels of rumen-degradable starch, as urea is diverted to support microbial digestion in the large intestine (Castillo et al., 2001b). In that report, concentrate supplements based on cornstarch reduced urinary $\mathrm{N}$ excre- 
Table 3. Least square means and SEM values for pasture intake, diet digestibility, and milk production in experiment 1.

\begin{tabular}{|c|c|c|c|c|}
\hline & $\mathrm{HP} 1^{1}$ & $\mathrm{HP} 6^{2}$ & $\mathrm{LP}^{3}{ }^{3}$ & SEM \\
\hline Pasture DMI (kg/d) & $15.4^{\mathrm{a}}$ & $13.9^{\mathrm{ab}}$ & $13.4^{\mathrm{b}}$ & 0.96 \\
\hline Total DMI (kg/d) & $16.2^{\mathrm{a}}$ & $18.9^{\mathrm{b}}$ & $18.4^{\mathrm{b}}$ & 0.92 \\
\hline Diet $\mathrm{DMD}^{4}(\mathrm{~g} / \mathrm{kg})$ & 782 & 792 & 774 & 23.6 \\
\hline Milk yield $(\mathrm{kg} / \mathrm{d})$ & $27.6^{\mathrm{a}}$ & $32.3^{\mathrm{b}}$ & $29.6^{\mathrm{ab}}$ & 1.47 \\
\hline Milk total protein $(\mathrm{g} / \mathrm{kg})$ & 3.22 & 3.21 & 3.17 & 0.05 \\
\hline Milk protein yield $(\mathrm{g} / \mathrm{d})$ & $888^{\mathrm{a}}$ & $1000^{b}$ & $934^{\mathrm{ab}}$ & 40.4 \\
\hline Milk fat (g/kg) & 4.06 & 4.24 & 4.21 & 0.26 \\
\hline Milk fat yield (g/d) & 1097 & 1212 & 1192 & 84.6 \\
\hline
\end{tabular}

\footnotetext{
${ }^{\mathrm{a}, \mathrm{b}}$ Within a row, means lacking a common superscript differ $(P<0.05)$.

${ }^{1} \mathrm{HP} 1$ = diet based on grazed pasture plus $1 \mathrm{~kg}$ of high protein concentrate.

${ }^{2} \mathrm{HP} 6=$ diet based on grazed pasture plus $6 \mathrm{~kg}$ of high protein concentrate.

${ }^{3} \mathrm{LP} 6=$ diet based on grazed pasture plus $6 \mathrm{~kg}$ of low protein concentrate.

${ }^{4} \mathrm{DMD}=\mathrm{DM}$ digestibility.
}

tion in comparison with concentrates based on barley starch for lactating cows fed grass silage-based diets. It is possible that, in this experiment, the barley in $\mathrm{NaB}$ had similar ruminal degradability compared with the barley in $\mathrm{RB}$, although it has been previously reported that $\mathrm{NaOH}$-treated barley has a lower effective ruminal degradability than rolled barley (McNiven et al., 1995). However, it should be noted that the milk urea $\mathrm{N}$ concentration was lower $(P<0.05)$ and urinary urea N:urinary creatinine $\mathrm{N}$ tended to be lower $(P<$ 0.12 ) for $\mathrm{NaB}$ (Table 6). For both urine $\mathrm{N}$ excretion and fecal $\mathrm{N}$ excretion, significant linear and curvilinear relationships were found between $\mathrm{N}$ intake and $\mathrm{N}$ excretion (Eq. [6] and [7]). As $\mathrm{N}$ intake increases, these relationships suggest that urine $\mathrm{N}$ excretion increases at a decreasing rate and fecal $\mathrm{N}$ excretion increases at an increasing rate (Figure 2). The relationship between milk $\mathrm{N}$ excretion and $\mathrm{N}$ intake did not demonstrate any significant curvilinear component (Eq. [8]). No significant relationships were observed between $\mathrm{N}$ intake and $\mathrm{N}$ excretion as a proportion of ingested $\mathrm{N}$ or the proportion of $\mathrm{N}$ excreted in the feces and urine that was ex- creted in the urine $(P>0.05)$. The relationship between milk urea $\mathrm{N}$ concentration and urine $\mathrm{N}$ excretion $(\mathrm{kg} /$ d) was also not significant. The relationships between milk urea $\mathrm{N}$ excretion $(\mathrm{mg} / \mathrm{d})$ and urine $\mathrm{N}$ excretion and between milk urea $\mathrm{N}$ excretion $(\mathrm{mg} / \mathrm{d})$ and the proportion of excreted $\mathrm{N}$ excreted in the urine were also not significant. Faverdin and Verite (1998) have reported a relationship between milk urea $\mathrm{N}$ concentration and urinary $\mathrm{N}$ excretion. However, it is unlikely that many of the data used to develop these relationships were based on grazed pasture. It is unclear why similar relationships were not found in the data in experiment 2 , but the lower milk urea $\mathrm{N}$ concentration observed for cows fed $\mathrm{NaB}$ might indicate a difference in $\mathrm{N}$ metabolism between the 2 groups that prevented such relationships being found. However, there was a relationship found between urinary urea $\mathrm{N}$ :creatinine $\mathrm{N}$ and urinary $\mathrm{N}$ excretion for the cows fed RB only $(P=0.05)$.

$$
\begin{gathered}
\text { Urine } \mathrm{N}(\mathrm{kg} / \mathrm{d})=-0.574( \pm 0.2910)+2.43( \pm 0.933) \times \mathrm{N} \\
\text { intake }(\mathrm{kg} / \mathrm{d})-1.50( \pm 0.737) \times \mathrm{N} \text { intake }(\mathrm{kg} / \mathrm{d})^{2} ; \\
R^{2}=0.80 ; P<0.0001
\end{gathered}
$$

Table 4. Least square means and SEM for $\mathrm{N}$ intake and $\mathrm{N}$ excretion data for dairy cows in experiment 1.

\begin{tabular}{llllr}
\hline & HP1 & HP6 & LP6 & SEM \\
\hline N intake (g/d) & $499^{\mathrm{a}}$ & $618^{\mathrm{b}}$ & $482^{\mathrm{a}}$ & 28.5 \\
Milk N (g/d) & 144 & 152 & 141 & 9.8 \\
Fecal N excretion (g/d) & 132 & 154 & 154 & 16.5 \\
Urine N excretion (g/d) & $223^{\mathrm{a}}$ & $312^{\mathrm{b}}$ & $186^{\mathrm{a}}$ & 30.6 \\
Total N excretion (g/d) & $355^{\mathrm{a}}$ & $467^{\mathrm{b}}$ & $340^{\mathrm{a}}$ & 26.6 \\
Milk N/N intake (\%) & $28.9^{\mathrm{ab}}$ & $25.3^{\mathrm{b}}$ & $29.5^{\mathrm{a}}$ & 1.87 \\
N excretion/N intake (\%) & $71.1^{\mathrm{ac}}$ & $74.7^{\mathrm{ab}}$ & $70.5^{\mathrm{c}}$ & 1.88 \\
Urine N/total N excretion (\%) & $62.3^{\mathrm{a}}$ & $66.3^{\mathrm{a}}$ & $53.7^{\mathrm{b}}$ & 5.38 \\
\hline
\end{tabular}

a,b,c Within a row, means lacking a common superscript differ $(P<0.05)$.

${ }^{1} \mathrm{HP} 1$ = diet based on grazed pasture plus $1 \mathrm{~kg}$ of high protein concentrate.

${ }^{2} \mathrm{HP} 6$ = diet based on grazed pasture plus $6 \mathrm{~kg}$ of high protein concentrate.

${ }^{3} \mathrm{LP} 6=$ diet based on grazed pasture plus $6 \mathrm{~kg}$ of low protein concentrate. 


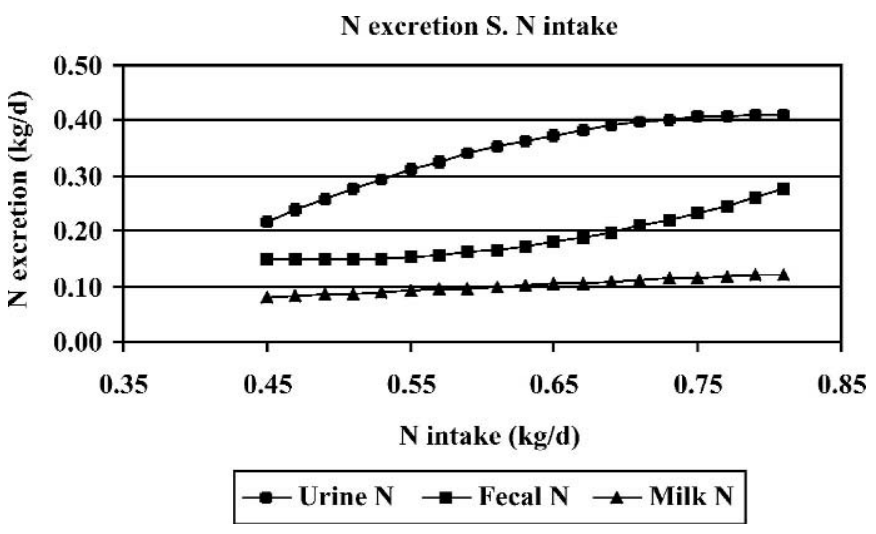

Figure 2. Pattern of urinary, fecal, and milk $\mathrm{N}$ excretion plotted over the $\mathrm{N}$ intake range observed for cows in experiment 2.

$$
\begin{gathered}
\text { Fecal } \mathrm{N}(\mathrm{kg} / \mathrm{d})=0.439( \pm 0.215)-1.19( \pm 0.690) \times \mathrm{N} \\
\text { intake }(\mathrm{kg} / \mathrm{d})+1.22( \pm 0.544) \times \mathrm{N} \text { intake }(\mathrm{kg} / \mathrm{d})^{2} ; \\
R^{2}=0.76 ; P<0.0001
\end{gathered}
$$

$$
\begin{array}{r}
\text { Milk N }(\mathrm{kg} / \mathrm{d})=0.0262( \pm 0.0245)+0.119( \pm 0.03866) \\
\times \text { N intake }(\mathrm{kg} / \mathrm{d}) R^{2}=0.33 ; P<0.01
\end{array}
$$

\section{Pasture DMI and Milk Production}

In experiment 1 , total DMI was higher $(P<0.05)$ for cows fed HP6 and LP6 than for cows fed HP1 (Table $3)$. Pasture DMI was only reduced $(P<0.05)$ in comparison to HP1 when the supplement contained a low CP content (i.e., LP6). The average substitution rate for cows fed LP6 was 0.47; cows fed HP6 had a lower substitution rate, 0.35 . Thus, it would appear that the higher content of CP in HP6, which came from soybean meal, stimulated pasture DMI in comparison to cows fed a concentrate containing no soybean meal. Several experiments examining the effect of feeding supplementary
RDP around the level of requirement have demonstrated no significant effect on DMI or milk production (Sloan et al., 1988; Colin-Schoelon et al., 2000). Schor and Gagliostro (2001) reported that replacing soybean meal with blood meal in the diet of dairy cows increased the intake of a perennial ryegrass/red clover pasture from 13.7 to $17.2 \mathrm{~kg} / \mathrm{d}$. Thus, supplementation of grazing dairy cows with RUP may be necessary to maximize DMI as the CP in the basal diet usually has a high ruminal degradability (Bargo et al., 2003), which may explain the higher pasture DMI observed for cows fed HP6.

In experiment 1 , mean milk yield was higher $(P<$ 0.01) for cows fed HP6 than for cows fed HP1 (Table $3)$. Cows fed HP6 tended $(P=0.083)$ to produce more milk than cows fed LP6. There were no effects of diet observed on milk protein or milk fat concentration $(P$ $>0.16$ ). Milk protein yield was affected by diet; the milk protein yield for cows fed HP6 was higher $(P<0.05)$ than the milk protein yield observed for cows fed HP1. Interestingly, the milk protein yield observed for cows fed LP6 was not statistically lower $(P>0.13)$ than the milk protein yield observed for cows fed HP6 (Table 3). Increasing $\mathrm{N}$ intake for dairy cows usually increases milk protein output even if at very low efficiencies at high $\mathrm{N}$ intake levels (Castillo et al., 2000). In experiment 1 , the increased $\mathrm{N}$ intake for cows fed diet HP6 in comparison to LP6 did not result in a significant increase $(P>0.05)$ in milk protein output, where DMI was similar for both treatments. Other researchers have demonstrated that $\mathrm{N}$ intake for dairy cows may be reduced without a reduction in milk protein output (Bach et al., 2000). In experiment 1, milk protein yield was numerically lower for cows fed HP1 than for cows fed LP6 (888 vs. $934 \mathrm{~g} / \mathrm{d}$ ) although N intake was higher for cows fed HP1. This result may be due to the extra energy intake for the cows fed LP6. Teller and Goodeau (1989) have demonstrated that the efficiency of utilization of intestinally absorbed $\mathrm{N}$ is increased for cows fed

Table 5. Dietary intake, digestibility, and milk production values observed for late lactation cows fed rolled or $\mathrm{NaOH}$-treated barley at pasture in experiment 2 .

\begin{tabular}{lcccc}
\hline & $\begin{array}{c}\text { Rolled } \\
\text { barley }\end{array}$ & $\begin{array}{l}\text { NaOH- } \\
\text { treated } \\
\text { barley }\end{array}$ & SEM & $P>F$ \\
\hline Pasture DMI (kg/d) & 14.8 & 15.1 & 0.78 & 0.749 \\
Concentrate DMI (kg/d) & 4.4 & 4.7 & 0.09 & 0.020 \\
Total DMI (kg/d) & 19.2 & 19.8 & 0.78 & 0.548 \\
Diet DMD 1 (\%) & 70.9 & 71.5 & 1.31 & 0.712 \\
Milk yield (kg/d) & 17.4 & 15.8 & 0.56 & 0.068 \\
Milk total protein (g/kg) & 3.78 & 3.82 & 0.07 & 0.728 \\
Milk total protein yield (g/d) & 658 & 597 & 20.2 & 0.058 \\
Milk fat (g/kg) & 4.46 & 4.32 & 0.11 & 0.349 \\
Milk fat yield (g/d) & 768 & 688 & 26.8 & 0.059 \\
\hline
\end{tabular}

${ }^{1} \mathrm{DMD}=\mathrm{DM}$ digestibility. 
Table 6. Nitrogen excretion data for late lactation cows fed rolled or NaOH-treated barley at pasture in experiment 2 .

\begin{tabular}{lcccc}
\hline & $\begin{array}{c}\text { Rolled } \\
\text { barley }\end{array}$ & $\begin{array}{l}\text { NaOH- } \\
\text { treated } \\
\text { barley }\end{array}$ & SEM & $P>F$ \\
\hline N intake (g/d) & 620 & 632 & 27.5 & 0.749 \\
Milk N (g/d) & 106 & 99.0 & 6.04 & 0.352 \\
Fecal N (g/d) & 181 & 193 & 13.1 & 0.488 \\
Urine N (g/d) & 331 & 342 & 19.7 & 0.649 \\
Milk N /N intake (\%) & 17.0 & 16.0 & 0.83 & 0.334 \\
N excretion /N intake (\%) & 82.6 & 84.3 & 0.80 & 0.123 \\
Urine N excretion/total N excretion (\%) & 64.8 & 63.6 & 1.79 & 0.592 \\
Milk urea N (mg/dL) & 18.7 & 15.6 & 1.12 & 0.042 \\
Urinary urea N:urinary creatinine N & 38.4 & 33.7 & 2.13 & 0.118 \\
Urinary allantoin N:urinary creatinine N & 2.71 & 2.52 & 0.160 & 0.362 \\
\hline
\end{tabular}

$110 \%$ of ME requirements in comparison with cows fed $90 \%$ of $\mathrm{ME}$ requirements.

The substitution rates observed for pasture DMI in experiment $1,0.35$ and 0.47 , are within the range $(0.02$ to 0.71 ) of those reviewed by Bargo et al. (2003). Similar substitution rates of 0.44 to 0.54 have been reported by Kennedy et al. (2003) for dairy cows yielding 27.5 to $31.9 \mathrm{~kg}$ of milk/d and fed up to $5.4 \mathrm{~kg}$ of concentrate $\mathrm{DM}$ as a supplement to perennial ryegrass-based pasture and by Bargo et al. (2002) (0.26 to 0.55) for dairy cows yielding 19.1 to $29.9 \mathrm{~kg}$ of milk/d and grazing a predominantly smooth bromegrass and orchardgrass pasture supplemented with $8.7 \mathrm{~kg}$ of concentrate DM. In experiment 1 , the average milk yield response for cows fed HP6 was $1.12 \mathrm{~kg}$ of milk/kg of extra concentrate $\mathrm{DM}$ fed, whereas the average milk yield response for cows fed LP6 was $0.47 \mathrm{~kg}$ of milk/kg of extra concentrate DM fed. In comparison, Bargo et al. (2002) reported milk responses of 0.96 and $1.36 \mathrm{~kg}$ of milk/kg of extra concentrate DM fed at high and low pasture allowances, respectively. Bargo et al. (2003) has stated that substitution rate is one of the main factors explaining variation observed in milk response to concentrate supplementation. However, total DMI was similar for cows fed HP6 and LP6. Other researchers have demonstrated that increasing dietary $\mathrm{CP}$ concentration may increase milk yield and or milk protein production where DMI has remained unchanged (Volden, 1999). Thus, a significant component of the difference in milk response between cows fed HP6 and cows fed LP6 might have been the lower metabolizable protein supply for cows fed LP6. This result agrees with Bargo et al. (2003) who reported from previously published literature that the mean increase in milk production was $0.8 \mathrm{~kg} / \mathrm{d}$ for every $100 \mathrm{~g}$ of RUP ingested.

In experiment 2, pasture DMI ranged from 9.9 to 19.7 $\mathrm{kg} / \mathrm{d}$ (Table 5). Barley processing method had no effect on pasture DMI $(P=0.75)$. Diet DMD was lower than in experiment 1 . Although no differences in total DMI or dietary DMD were observed, the mean milk yield observed for cows fed RB $(17.4 \mathrm{~kg} / \mathrm{d})$ tended to be higher $(P<0.07)$ than the mean milk yield observed for cows fed $\mathrm{NaB}(15.8 \mathrm{~kg} / \mathrm{d})$. Milk protein yield $(658 \mathrm{~g} / \mathrm{d})$ and milk fat yield $(768 \mathrm{~g} / \mathrm{d})$ tended to be higher $(P<0.06)$ for cows fed RB than for cows fed $\mathrm{NaB}$ (Table 5).

\section{CONCLUSIONS}

These experiments demonstrate that a lower proportion of excreted $\mathrm{N}$ is excreted in the urine of dairy cows when concentrate supplements containing low concentrations of CP and high concentrations of fermentable $\mathrm{OM}$ are fed as supplements to dairy cows grazing perennial ryegrass-based pasture. A greater proportion of ingested $\mathrm{N}$ is excreted in the feces and urine of springcalving dairy cows grazing perennial ryegrass-based pasture in later lactation as a consequence of the lower protein requirements of these cows and high pasture $\mathrm{N}$ concentrations in the fall (Table 2). For diets of high digestibility, increasing $\mathrm{N}$ intake increases $\mathrm{N}$ excretion in urine, milk, and feces linearly, with the highest rates of increase observed for urinary $\mathrm{N}$ excretion. For diets of lower digestibility, fecal $\mathrm{N}$ excretion increases in importance relative to urinary $\mathrm{N}$ at high levels of $\mathrm{N}$ intake (Figure 2). The substitution rate of concentrates for pasture in grazing dairy cows is lower for high CP concentrate supplements. Given that cows fed the low and high CP concentrates had quite similar total DMI, it is likely that some of the extra milk yield response of the cows fed the high CP supplement is attributable to an increase in supply of true protein truly digestible in the small intestine.

\section{ACKNOWLEDGMENTS}

This work was co-funded by The Irish Department of Education and Science through The Higher Education Authority as part of a postdoctoral fellowship. 


\section{REFERENCES}

Bach, A., G. B. Huntington, S. Calsamiglia, and M. D. Stern. 2000. Nitrogen metabolism of early lactation cows fed diets with two different levels of protein and two different amino acid profiles. J. Dairy Sci. 83:2585-2595.

Bargo, F., L. D. Muller, J. E. Delahoy, and T. W. Cassidy. 2002. Milk response to concentrate supplementation of high producing dairy cows grazing at two pasture allowances. J. Dairy Sci. 85:17771792.

Bargo, F., L. D. Muller, E. S. Kolver, and J. E. Delahoy. 2003. Invited review: Production and digestion of supplemented dairy cows on pasture. J. Dairy Sci. 86:1-42.

Borcher, R. 1977. Allantoin determination. Anal. Biochem. 79:612613.

Castillo, A. R., E. Kebreab, D. E. Beever, J. H. Barbi, J. D. Sutton, H. C. Kirby, and J. France. 2001a. The effect of protein supplementation on nitrogen utilization in lactating dairy cows fed grass silage based diets. J. Anim. Sci. 79:247-253.

Castillo, A. R., E. Kebreab, D. E. Beever, J. H. Barbi, J. D. Sutton, H. C. Kirby, and J. France. 2001b. The effect of energy supplementation on nitrogen utilization in dairy cows fed grass silage diets. J. Dairy Sci. 79:240-246.

Castillo, A. R., E. Kebreab, D. E. Beever, and J. France. 2000. A review of efficiency of nitrogen utilisation in lactating dairy cows and its relationship with environmental pollution. J. Anim. Feed Sci. 9:1-32.

Colin-Schoelon, O., S. Jurjanz, and F. Laurent. 2000. Metabolizable protein supply (PDIE) and restricted level of ruminally degradable nitrogen (PDIN) in total mixed rations: Effect on milk production and composition and on nitrogen utilization by dairy cows. Livest. Prod. Sci. 67:41-53.

Dillon, P. 1993. The use of n-alkanes as markers to determine intake, botanical composition of available or consumed herbage in studies of digesta kinetics with dairy cows. Ph.D. Thesis, Natl. Univ. of Ireland, University College Cork.

Dillon, P., and G. Stakelum. 1989. Herbage and dosed alkanes as a grass measurement technique for dairy cows. Ir. J. Agric. Res. 28:104. (Abstr.)

Faverdin, P., and R. Verite. 1998. Use of milk urea concentration as an indicator of protein nutrition and nitrogen losses in dairy cows. Renc. Rech. Ruminants 5:209-212.

Hvelplund, T., and J. Madsen. 1996. Protein utilization in ruminants. Pages 83-89 in Proc. of the 7th Int. Symp., Protein Metabolism and Nutrition. A. F. Nunes, J. P. Costa, and J. R. Ribeiro, ed. EAAP Publ. No. 81. Wageningen Press, Wageningen, The Netherlands.

Kebreab, E., A. R. Castillo, D. E. Beever, D. J. Humphries, and J. France. 2000. Effects of management practices prior to and during ensiling and concentrate type on nitrogen utilization in dairy cows. J. Dairy Sci. 83:1274-1285.

Kennedy, J., P. Dillon, L. Delaby, P. Faverdin, G. Stakelum, and M. Rath. 2003. Effect of genetic merit and concentrate supplementa- tion on grass intake and milk production with Holstein Friesian dairy cows. J. Dairy Sci. 86:610-621.

Lockyer, D. R., and D. C. Whitehead. 1990. Volatilization of ammonia from cattle urine applied to grassland. Soil Biol. Biochem. 22:1137-1142.

Mayes, R. W., C. S. Lamb, and P. M. Colgrove. 1986. The use of dosed and herbage n-alkanes as markers for the determination of herbage intake. J. Agric. Sci. (Camb.) 107:161-170.

McNiven, M. A., M. R. Weisbjerg, and T. Hvelplund. 1995. Influence of roasting and sodium hydroxide treatment of barley on digestion in lactating cows. J. Dairy Sci. 78:1106-1115.

Mulligan, F. J., P. J. Caffrey, M. Rath, J. J. Callan, P. O. Brophy, and F. P. O'Mara. 2002. An investigation of feeding level effects on digestibility in cattle for diets based on grass silage and high fibre concentrates at two forage:concentrate ratios. Livest. Prod. Sci. 77:311-323.

National Research Council. 2001. Nutrient Requirements of Dairy Cattle. 7th rev. ed. Natl. Acad. Press. Washington, DC.

O’Mara, F. P., J. J. Murphy, and M. Rath. 1997. The effect of replacing dietary beet pulp with wheat treated with sodium hydroxide, ground wheat or ground corn in lactating cow diets. J. Dairy Sci. 80:530-540.

Pakrou, N., and P. Dillon. 1995. Preferential flow, nitrogen transformations and $15 \mathrm{~N}$ balance under urine affected areas of irrigated and non-irrigated clover based pastures. J. Contam. Hydrol. 20:329-347.

Peyraud, J. L., and L. Astigarraga. 1998. Review of the effect of nitrogen fertilization on the chemical composition, intake, digestion and nutritive value of fresh herbage: Consequences on animal nutrition and $\mathrm{N}$ balance. Anim. Feed Sci. Technol. 72:235-259.

Schor, A., and G. A. Gagliostro. 2001. Undegradable protein supplementation to early-lactation dairy cows in grazing conditions. J. Dairy Sci. 84:1597-1606.

Sloan, B. K., P. Rowlinson, and D. G. Armstrong. 1988. Milk production in early lactation dairy cows given grass silage ad-libitum: Influence of concentrate energy source, crude protein content and level of concentrate allowance. Anim. Prod. 46:317-331.

STAT Guide for Personal Computer. 1985. SAS Inst., Inc., Cary, NC. Tamminga, S. 1992. Nutrition management of dairy cows as a contribution to pollution control. J. Dairy Sci. 75:345-357.

Teller, E., and J. M. Goodeau. 1989. Protein and energy relationships in dairy cattle. 2. Lactating cows. Archiv. Anim. Nutr. 39:543-551.

Van Vuuren, A. M., C. J. Van Der Koelen, H. Valk, and H. De Visser. 1993. Effects of partial replacement of ryegrass by low protein feeds on rumen fermentation and nitrogen loss by dairy cows. J. Dairy Sci. 76:2983-2993.

Volden, H. 1999. Effects of level of feeding and ruminally undegraded protein on ruminal bacterial protein synthesis, escape of dietary protein, intestinal amino acid profile, and performance of dairy cows. J. Anim. Sci. 77:1905-1918.

Wu, Z., and L. D. Satter. 2000. Milk production during the complete lactation of dairy cows fed diets containing different amounts of protein. J. Dairy Sci. 83:1042-1051. 